\section{Influence of IAA and IBA on root development and quality of Prunus 'GiSelA 5' leafy cuttings}

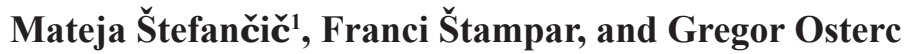 \\ University of Ljubljana, Biotechnical Faculty, Agronomy Department, \\ Jamnikarjeva 101, 1000 Ljubljana, Slovenia
}

Additional index words. auxin, indole-3-acetic acid, indole-3-butyric acid, propagation, rooting, rootstock

\begin{abstract}
The influence of two exogenously applied auxins (IAA and IBA) on the root and shoot development of leafy cuttings was analyzed at 'GiSelA 5', the dwarfing cherry rootstock. IBA (indole-3-butyric acid) hindered the callus formation in the early period of root development and it was more successful than IAA (indole-3-acetic acid) in promoting earlier root development. IBA also influenced the stronger shoot growth and the development of acrobasal type of the rooting system, and induced higher number of roots. Those parameters are very important for the quality and survival of the new plants and they are not the consequence of the higher IAA content in the rooting zones of cuttings in the first days of root development. Both auxin treatments had no effect on the final percent of the rooted cuttings neither on the survival of cuttings, but they increased the percent of rooted cuttings without callus. The root system with callus proved less qualitative, because the cuttings with such root system developed significantly less roots per rooted cutting and their shoot length was shorter than those of the cuttings without callus at both auxin treatments. Exogenously applied auxins were not crucial for root formation, however their application resulted in higher percent of more qualitative 'GiSelA 5' leafy cuttings. IBA proved as the most efficient treatment and it additionally induced earlier root formation.
\end{abstract}

Propagation of the difficult-to-root plant species becomes commercially feasible with the establishment of the optimal propagation method. A key step in vegetative propagation is adventitious root formation. Losses occur because of the poor quality of the root system or of the shoot and because of poor or slow rooting (De Klerk et al., 1999).

The process of adventitious root formation is influenced by a number of internal and external factors (Davis et al., 1988). Among internal factors, the most important role is ascribed to phytohormones, especially the auxins. It is generally accepted that auxins have a certain role in the rooting initiation (Davis et al., 1988; Hartman et al., 1997). Divisions of the first root initial cells are dependent on either endogenous or applied auxins (Hartman et al., 1997). IAA is generally regarded as the major auxin, universally found in higher plants, that plays a central role in adventitious rooting (Davis et al., 1988; De Klerk et al., 1999). There is no direct evidence that the synthetic auxins might substitute for a natural one in cells (Davis et al., 1988), but they can reach the plant's IAA-pool (Bartel et al., 2001).

IAA is the main auxin in most plants, while IBA is the most common exogenously applied plant growth regulator(Davies, 1995; De Klerk et al., 1999). IBA has a weak auxin activity, but is relatively stable and insensitive to the auxin degrading enzyme systems (Epstein

Received for publication 27 May 2005. Accepted for publication 11 July 2005.

${ }^{1}$ To whom reprint request should be addressed; e-mail mateja.trobec@bf.uni-lj.si. 1991; Riov, 1993). It has even greater ability to promote adventitious root formation than 2000; Spethmann and Hamzah, 1988; Wiesman et al., 1988, 1989), probably because of the higher stability of IBA. IBA is especially preferable in in vivo conditions, where auxin is taken up during a brief initial period. IAA is rapidly oxidized by the plant tissue, while IBA conjugates (especially indole-3-acetylaspartic acid) serve as the source of auxin during the later stages of rooting (Epstein and LudwigMüller, 1993; Nordström et al., 1991; Wiesman etal., 1988, 1989). Some evidence suggests that IBA acts as an auxin on its own, not through its conversion to IAA (Ludwig-Müller, 2000). However, biochemical studies in numerous plants and genetic studies of Arabidopsis IBA-mutants indicate that IBA acts primarily via its conversion to IAA, which occurs in a mechanism similar to peroxisomal fatty acid $\beta$-oxidation (Nordström et al., 1991).

The present work investigated the rooting of 'GiSelA 5', a commercially important cherry dwarfing rootstock. Prunus spp. are generally classified as difficult-to-root species (Davies and Hartmann, 1988; Spethmann, 2000), therefore treatment with auxin is necessary for their better rooting. We investigated the difference in efficiency of the two applied auxins, IAA and IBA in comparison with untreated cuttings and examined the influence of auxins on the quality of the new plants and on the earliness of the root system development. Rooting experiments are usually designed in such a manner that quality parameters are measured and Ludwig-Müller, 1993; Nordström et al., IAA (De Klerk et al., 1999; Ludwig-Müller, at the final stage of an experiment. This can be at the end of the growing season or around one month after the establishment of cuttings. Rooting parameters at the end of the growing season are important for the evaluation of the efficiency of the propagating method (survival of the cuttings, quality of plants), while the results soon after root emergence are good for the evaluation of the earliness of rooting. We combined these two approaches and performed the cuttings evaluation at both time periods to present the differences between the results and to determine the earliness of the root development.

\section{Materials and Methods}

Experiment. Terminal shoots were collected from 5-year-old in vitro derived stock plants of 'GiSelA 5' (P. cerasus $\times$ P. canescens $-148 / 2)$ in the middle of June and adjusted to $15 \mathrm{~cm}$ long leafy cuttings with the apical meristems. Cuttings had on average three to four expanded leaves.

One-third of cuttings were quick-dipped (for about $5 \mathrm{~s}$ ) into the $4 \mathrm{~g} \cdot \mathrm{L}^{-1}(=22.8 \mathrm{mM})$ IAA solution, the second third of cuttings were dipped for $5 \mathrm{~s}$ into the $4 \mathrm{~g} \cdot \mathrm{L}^{-1}(=19.7$ $\mathrm{mM}$ ) IBA solution (the auxins were dissolved in pure ethanol and filed up with water to obtain $2 \%$ ethanol-aqueous solution), while the control cuttings were dipped into the nonauxin quick-dip solution and put directly into the wet 3 peat : 1 sand substrate with slow-released fertilizers (Osmocote Exact $16+11+11+3 \mathrm{Mg}+\mathrm{Te})$. All 3 treatments were replicated 3 times with 40 cuttings per plot, and extra cuttings ( 6 cuttings per plot for each day of collecting data) were used for the analysis of IAA. The experiment was carried out in an unheated greenhouse under the fog system. The greenhouse is located in Ljubljana, the capital of Slovenia, Europe (latitude $=46.22$ $\mathrm{N}$; longitude $=14.48 \mathrm{E}$ ). Cuttings were made in the conditions of the longest daylength; in the June the day lasted for almost $16 \mathrm{~h}$. During the rooting, average $40 / 18{ }^{\circ} \mathrm{C}$ day/night temperatures were obtained in the greenhouse. The high day temperatures did not harmed the cuttings because of the high relative humidity. Fogging, based on high-pressure foggers, was regulated manually to obtain averagely $95 \%$ to $100 \%$ humidity. The fogging intervals lasted about $30 \mathrm{~s}$, followed by a 60 -s pause. During the night (from 7 PM to $7 \mathrm{AM}$ ) fogging was not carried out. The pause intervals were extended in the late August, whereas the device was completely stopped in the late September.

First experimental data were collected 1 month after the establishment of cuttings (summer results). Rooting rate, callus formation and root length of 10 cuttings from each experimental unit were evaluated. As this evaluation disturbs growth, we eliminated them from further analyses. At the end of the rooting season (in January), the remaining cuttings were examined for rooting rate, callus formation, number of main roots, shoot growth (the total length of all shoots formed by the individual cuttings), root length and the way of development of roots (winter results). 
Extraction and analysis of IAA. The cuttings were collected on the cutting day and 1, 2, 3, 4, and 5 d later. Samples, the basal 3-cm portions of the cuttings, were stored at $-80^{\circ} \mathrm{C}$ until the analysis; other parts of cuttings were discarded. Each sample contained cutting bases of six cuttings to obtain enough material for IAA extraction.

IAA was extracted following a method of Kovač et al. (2003) with slight modifications. The samples were ground to powder by mortar and pestle. Each sample was divided into 3 portions of $0.2 \mathrm{~g}$ and separately extracted with $6 \mathrm{~mL}$ of BHT-MeOH solution $\left(0.5 \mathrm{~g} \cdot \mathrm{L}^{-1}\right)$. To one of 3 repetitions, standard (IAA) was added. After $1 \mathrm{~h}$ at $4{ }^{\circ} \mathrm{C}$, the extract was filtered and 3 $\mathrm{mL}$ of $5 \mathrm{~mm} \mathrm{~K}$-phosphate buffer (pH 6.5) was added to each sample. For the purification of IAA, we used Strata C18-E columns from Phenomenex. The complete sample extracts were first run through the column conditioned at $\mathrm{pH}$ 6.5 and washed with $4 \mathrm{~mL}$ of $5 \mathrm{~mm} \mathrm{~K}$-phosphate buffer, $\mathrm{pH}$ 6.5. The eluate was acidified with $20 \mathrm{~mm} \mathrm{HCl}$ to $\mathrm{pH} 2.5$ and applied to a second column conditioned at $\mathrm{pH} 2.5$. The column was rinsed with $2 \mathrm{~mL}$ of double-distilled water and eluted with $2 \mathrm{~mL}$ of $80 \% \mathrm{MeOH}$.

The concentrated eluate $(1 \mathrm{~mL})$ was separated by TSP HPLC and Varian Chromsep column (SS $250 \times 4.6 \mathrm{~mm}$, hypersil 5 ODS) and analyzed with fluorescence (Spectrasystem FL2000) and UV-VIS (Knauer K-2500) detectors. The mobile phase consisted of solvent A: $1 \%$ acetic acid and solvent B: $\mathrm{MeOH}$. Gradient was linear from $10 \%$ to $55 \%$ of solvent $\mathrm{B}$ in 40 min and from $55 \%$ to $90 \%$ of solvent B in the last $5 \mathrm{~min}$. The flow rate was $1 \mathrm{~mL} \cdot \mathrm{min}^{-1}$. Excitation of fluorescence detector was at $254 \mathrm{~nm}$ and emission at $360 \mathrm{~nm}$; UV-VIS detector absorption was adjusted to $280 \mathrm{~nm}$. IAA was quantified by fluorimetry, comparing the peak areas with those of known amounts of IAA. Losses were evaluated by standards that had gone through the whole process of extraction and purification. The calculated IAA contents are the means of two replicate measurements.

\section{Results and Discussion}

The rooting in the present study was better than in our previously reported results (Trobec et al., 2005) (most likely due to improved propagating conditions, namely more frequent fogging with drainage system) and very comparable to the results reported by Osterc and Spethmann (1998). The final rooting was significantly equal for all treatments (Fig. 1). This fact was not observed for terminal cuttings in our previous experiment with the powder application of IBA (Trobec et al., 2005). It seems that the quick dip application is not as effective as the powder hormone application or that the concentration of applied IBA was not high enough. Similar results in Prunus spp. were obtained by Trefois and Brunner (in Davis et al. 1988), where no effect of the exogenous auxin treatment on the rooting in the case of low endogenous auxin level at the time when cuttings were prepared was observed. Compared to many other experiments (Baraldi et al., 1993, for pear cultivars; Nördstrom et al., 1991, for pea cuttings; Auderset et al., 1994, for apple rootstock cuttings), the concentrations of endogenous IAA in the bases of the terminal parts of 'GiSelA 5' shoots in our experiment were rather low (Table 1). That might be the reason for the lack of effect of the applied auxins.

One month after the establishment of cuttings, the percent of rooted cuttings treated with IBA was significantly higher than that of other cuttings (Fig. 1). Whereas this higher rooting percentage is comparable to that of etiolated 'GiSelA 5' cuttings from banded shoots in the experiment of Gulen et al. (2004), our technique is easier to handle. Furthermore, the control cuttings in this study rooted better than those of Gulen et al. (2004). This might have resulted from the use of a better propagating system (fog instead of mist) and it is perhaps partly due to physiologically younger micropropagated stock material.

From summer and winter results, it can be concluded that IBA treatment has an influence on the early development of the adventitious roots. However, comparing the results of bare callus formation from both evaluations, an important difference was observed. It is obvious that the time of the qualitative evaluation of growth parameters is very important for the interpretation of the experimental results.

Callus formation usually hinders rooting
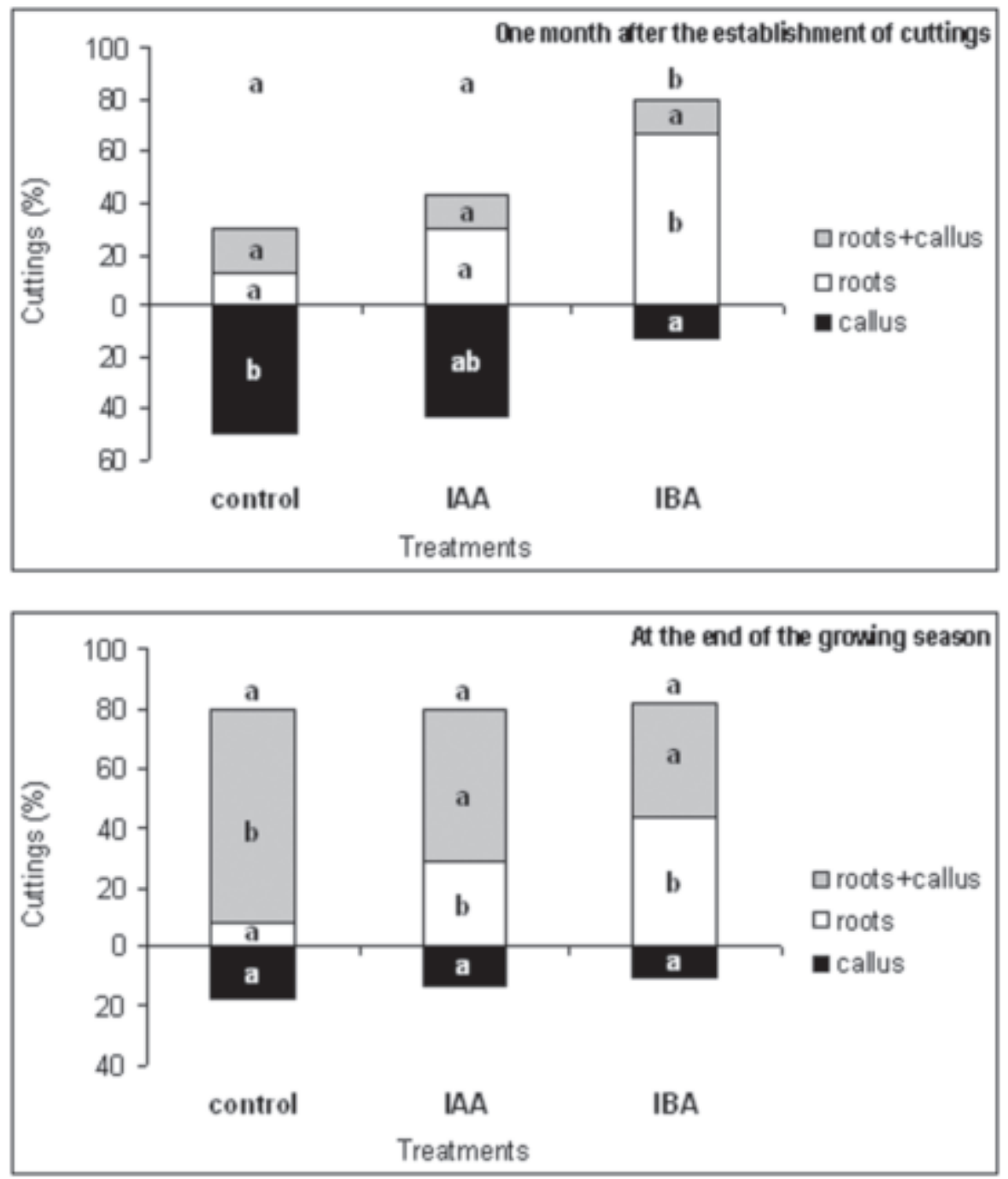

Fig. 1. Rooting and callus formation (\%) of 'GiSelA 5' leafy cuttings 1 month after the establishment of cuttings and at the end of the growing season, according to different treatments. Means for callus formation, root formation and callus with roots marked with the same letter are nonsignificant $(P=0.05$, LSD test), compared across the treatments. The letters above the bars indicate the statistical differences between the treatments with all rooted cuttings (regardless of callus formation).

Table 1. Internal levels of IAA (ng.g-1 of fresh weight) in the stem bases of leafy cuttings of 'GiSelA 5 ' until fifth day after the establishment of cuttings.

\begin{tabular}{lcccccc}
\hline & \multicolumn{6}{c}{ Days after the establishment of cuttings } \\
\cline { 2 - 7 } Treatments & 0 & 1 & 2 & 3 & 4 & 5 \\
\hline Control & 2.9 & $30.9 \mathrm{a}^{2}$ & $6.3 \mathrm{a}$ & $3.2 \mathrm{a}$ & $5.4 \mathrm{~b}$ & $4.2 \mathrm{a}$ \\
IAA & & $558.0 \mathrm{c}$ & $32.1 \mathrm{~b}$ & $5.2 \mathrm{a}$ & $2.8 \mathrm{a}$ & $2.6 \mathrm{a}$ \\
IBA & $147.8 \mathrm{~b}$ & $20.5 \mathrm{ab}$ & $5.7 \mathrm{a}$ & $4.8 \mathrm{ab}$ & $1.9 \mathrm{a}$ \\
\hline
\end{tabular}

${ }^{2}$ Values within a column followed by the same letter are nonsignificant at $P=0.05$ by a LSD test. 
formation process (Spethmann, 2000; Spethmann and Hamzah, 1988) and it can be the consequence of unusual hormonal proportion due to higher exogenous auxin treatment. The IAA treatment induced the highest accumulation of endogenous IAA on the first day after the establishment of cuttings (Table 1), but the concentration was not higher than with some other experiments (Nordström et al., 1991, for pea and Auderset et al., 1994, for apple rootstock cuttings). In the critical review on hormonal applications, Loach (1988) stated that for woody ornamental species doses higher than $8 \mathrm{~g} \cdot \mathrm{L}^{-1}$ are often damaging, but again the optimal endogenous concentration of IAA depends on the individual species and clones (Baraldi et al., 1993; Blakesley et al., 1991). The percent of bare callus formation of the cuttings 1 month after IAA treatment was higher than that in the experiment with ' GiSelA 4' by Osterc and Spethmann (2001), but the percent decreased by the end of the growing season. The decrease was also noticed with
IBA and control treatments (Fig. 1). Callus development is common with wound healing where it appears as a thin layer around the wounded end of cuttings. Spethmann and Hamzah (1988) stated that callus is not the originating point of roots, and it rather appears as to stop or delay root formation. More than $40 \%$ of IAA treated and control cuttings in our experiment developed bare callus after one month in the substrate. The percentages decreased by the end of the growing season in the favor of rooted cuttings with callus formation. This indicates late emergence of roots might be due to thick callus formation. Cuttings with the bare callus formation died by the end of the growing season.

Spethmann (2000) wrote that for the development of roots, the first few weeks after the cutting establishment are decisive. For the development of roots later in the season, exogenous auxin is ineffective, but endogenous biosynthesis of IAA should be responsible. De Klerk et al. (1999) declared that during the induction phase (in our case up to the first day after the establishment of cuttings, when IAA content is rising), auxin pulses induce the highest number of roots, while Blakesley et al. (1991) stated that cuttings develop the final number of roots when the level of IAA declines [in our case after the first day of cutting establishment (Table 1)]. Therefore, the roots of our cuttings should be initiated until the summer evaluation. However, 1 month after the establishment of cuttings, most of the roots of untreated cuttings and cuttings treated with IAA were not visible. These cuttings developed roots after the callus formation. This leads to the conclusion that thick callus postponed the root outgrowth in those treatments.

The control treatment gave the highest final percent of the plants with less qualitative rooting systems. The percent of the cuttings with callus $(72.2 \%)$ was higher than that without callus $(7.8 \%)$. From this point of view, IBA treatment was the most successful, because more than half of the rooted cuttings did not

\section{The vay of development of roots}

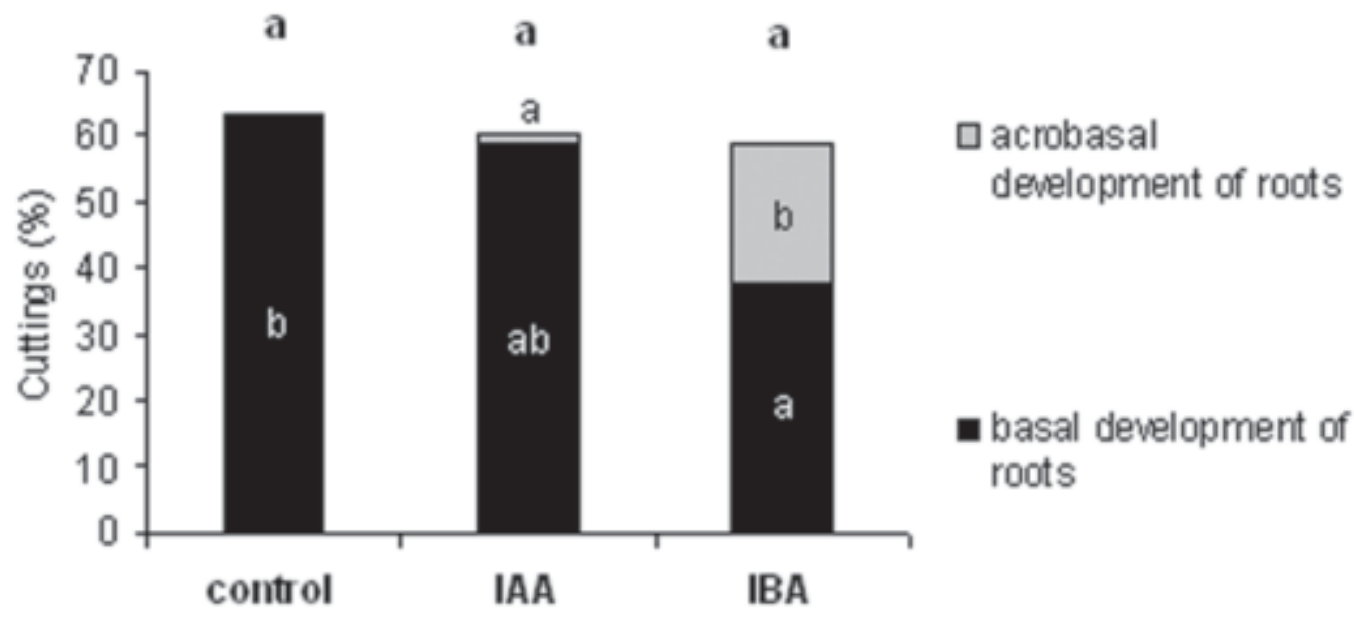

Treatments
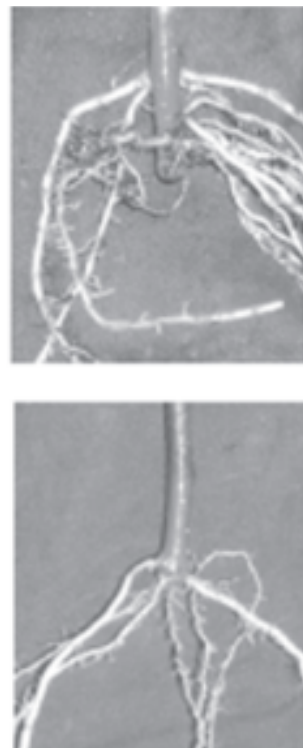

Fig. 2. The percentages of all living rooted cuttings according to the type of the developed rooting systems (acrobasal rooting systems/basal rooting systems) and different treatments (winter data). Mean percents of individual cutting types marked with the same letter are nonsignificant $(P=0.05$, LSD test), compared across the treatments. The letters above the bars indicate the statistical differences between the treatments with all living rooted cuttings (regardless of callus formation).

Table 2. The effect of the IAA and IBA treatments on the number of main roots, the root growth and the shoot growth (the total length of all shoots formed by on the rooted cuttings) of leafy cuttings of 'GiSelA 5' 1 month after establishment of cuttings (summer results) and at the end of the rooting season (winter results). Besides mean values of all rooted cuttings, the values for cuttings with the absence and presence of the callus formation are shown separately in winter results.

\begin{tabular}{|c|c|c|c|c|c|c|c|}
\hline \multirow[b]{3}{*}{ Parameter } & \multirow[b]{3}{*}{ Treatment } & \multirow{3}{*}{$\begin{array}{c}\begin{array}{c}\text { Summer } \\
\text { results }\end{array} \\
\begin{array}{c}\text { All rooted } \\
\text { cuttings }\end{array}\end{array}$} & \multirow{3}{*}{$\begin{array}{l}\text { Significance between } \\
\text { all rooted cuttings } \\
\text { of summer and } \\
\text { winter results }\end{array}$} & \multicolumn{4}{|c|}{ Winter results } \\
\hline & & & & & $\begin{array}{l}\text { Rooted } \\
\text { cuttings }\end{array}$ & $\begin{array}{l}\text { Rooted } \\
\text { cuttings }\end{array}$ & $\begin{array}{c}\text { Significance between } \\
\text { rooted cuttings }\end{array}$ \\
\hline & & & & $\begin{array}{l}\text { All rooted } \\
\text { cuttings }\end{array}$ & $\begin{array}{l}\text { without } \\
\text { callus }\end{array}$ & $\begin{array}{l}\text { with } \\
\text { callus }\end{array}$ & $\begin{array}{c}\text { with and } \\
\text { without callus }\end{array}$ \\
\hline \multirow[t]{3}{*}{ Number of main roots } & Control & $2.9 \mathrm{a}^{\mathrm{z}}$ & NS & $3.3 \mathrm{a}$ & $--^{y}$ & $3.1 \mathrm{a}$ & \\
\hline & IAA & $3.9 \mathrm{ab}$ & NS & $3.6 \mathrm{a}$ & $5.0 \mathrm{a}$ & $2.5 \mathrm{a}$ & $*$ \\
\hline & IBA & $7.0 \mathrm{~b}$ & NS & $6.5 \mathrm{~b}$ & $8.3 \mathrm{~b}$ & $4.3 \mathrm{a}$ & $*$ \\
\hline \multirow[t]{3}{*}{ Root length (cm) } & Control & $2.1 \mathrm{a}$ & $*$ & $14.6 \mathrm{a}$ & --- & $14.2 \mathrm{a}$ & \\
\hline & IAA & $5.0 \mathrm{~b}$ & $*$ & $15.3 \mathrm{a}$ & $17.2 \mathrm{a}$ & $14.2 \mathrm{a}$ & NS \\
\hline & IBA & $6.0 \mathrm{~b}$ & $*$ & $15.4 \mathrm{a}$ & $17.1 \mathrm{a}$ & $13.7 \mathrm{a}$ & $*$ \\
\hline \multirow[t]{3}{*}{ Shoot growth $(\mathrm{cm})$} & Control & $1.8 \mathrm{a}$ & $*$ & $17.9 \mathrm{a}$ & --- & $13.2 \mathrm{a}$ & \\
\hline & IAA & $1.3 \mathrm{a}$ & $*$ & $22.1 \mathrm{ab}$ & $34.7 \mathrm{a}$ & $11.4 \mathrm{a}$ & $*$ \\
\hline & IBA & $1.2 \mathrm{a}$ & $*$ & $29.0 \mathrm{~b}$ & $38.0 \mathrm{a}$ & $18.7 \mathrm{a}$ & $*$ \\
\hline
\end{tabular}

${ }^{\text {z}}$ Values within a column of each parametr followed by the same letter are nonsignificant at $P=0.05$ by a LSD test.

${ }^{y}$ Insufficient number of cuttings for proper statistics.

NS, ${ }^{*}$ Nonsignificant or significant at $P=0.05$, respectively. 
develop callus at the end of the growing season. The IBA treatment gave the highest rooting one month after the establishment of the cuttings, although some rooted cuttings subsequently developed callus.

The root system with callus is of lesser quality, because the cuttings with such root system developed significantly fewer roots per rooted cutting and their average shoot growth was weaker than those of the cuttings without callus at both auxin treatments, which brought about the longer roots one month after the treatments (Table 2). These results of 'GiSelA 5 ' leafy cuttings were similar to those of the reports of apple rootstock cuttings (Badshah et al., 1995) and 'GiSelA 5' cuttings (Gulen et al., 2004), in which the IBA treatments brought about the longer roots. Although the root lengths of all treatments became equal at the end of the growing season (Table 2). The common growth rate of cuttings at the end of the season was in the favor of IBA treated cuttings, which developed rooting systems of $15.4 \mathrm{~cm}$ on the average and the mean shoot growth of $29.0 \mathrm{~cm}$ per rooted cutting (Table 2 ).

IBA treatment produced a significantly higher percentage of cuttings with acrobasal root system development (Fig. 2). Similar findings were obtained by Spethmann and Hamzah (1988). IBA is known to induce a high number of adventitious roots (Badshah et al., 1995; Hartmann et al., 1997; LudwigMüller, 2000; Spethmann, 2000; Spethmann and Hamzah, 1988; Wiesman and Lavee, 1995; Wiesman et al., 1988) and this was evident also in our experiment, where IBA treated cuttings developed on average 6.5 roots per rooted cutting and IAA treated cuttings and untreated cuttings 3.6 and 3.3 roots per rooted cutting respectively. The mean number of roots in separate treatments stayed unchanged until the end of the season (Table 2). The parameters which define a better rooting system quality do not depend on the basal endogenous IAA concentration in the first days of the rooting process. One possibility for beneficial influence of IBA might be in providing the auxin over a longer period of time or that IBA conjugates are a better source of free auxin through hydrolysis than IAA conjugates (Nordström et al., 1991; Yang and Davies, 1999).

However, a more qualitative root system had no effect on the survival of cuttings at the end of the propagating season because all treatments produced significantly equal amount of living rooted cuttings (Fig. 2), but it did affect the shoot growth intensity, which is very important for the earliness of grafting in the next year. Significantly equal rooting percentages of treated and untreated cuttings indicate that auxin applications might have a greater effect on final rooting success of cuttings from less optimal propagating conditions. This can be seen when comparing our present and previous results (Trobec et al., 2005).

Earlier and more qualitative adventitious root and growth developments of cuttings treated with IBA are not a consequence of the highest, but probably the most optimal endogenous IAA concentrations (Table 1). It appears that IBA influenced the root formation more than IAA, or modulated the activity of IAA, as reported by Ludwig-Müller (2000) and Nordström et al. (1991). IBA also produced stronger shoot growth and the development of an acrobasal type of the rooting system. Thus, IBA appears to be a better plant growth regulator with the influence on the quality of new 'GiSelA 5' plants.

\section{Literature Cited}

Auderset, G., S.Gavillet, J. Micheli, J. O’Rourke, M Ribaux, and C. Moncousin. 1994. Histological analysis and the evolution of biochemical markers during the in vitro rooting of Malus domestica Borkh. 'Jork 9'. Adv. Hort. Sci. 8:5-10.

Badshah, N., N. Rahman, and M. Zubair. 1995. Effect of indolebutyric acid (IBA) on the cuttings of M-26 and M-27 apple rootstocks. Sarhad J. of Agr. XI:449-453.

Baraldi, R., G. Bertazza, S. Predieri, and A.M Bregoli. 1993. Uptake and metabolism of indole3-butyric acid during the in vitro rooting phase in pear cultivars (Pyrus communis). Acta Hort. 329:289-291.

Bartel, B., S. LeClere, M. Magidin, and B.K. Zolman. 2001. Inputs to the active indole-3-acetic acid pool: de novo synthesis, conjugate hydrolysis, and indole-3-butyric acid $\beta$-oxidation. J. Plant Growth Regulat. 20:198-216.

Blakesley, D., G.D. Weston, and J.F. Hall. 1991. The role of endogenous auxin in root initiation. Part I: Evidence from studies on auxin application, and analysis of endogenous levels. Plant Growth Regulat. 10:341-353.

Davies, P.J. 1995. Plant hormones. Physiology, biochemistry and molecular biology. Second edition, p. 833. Kluwer Academic Publishers, Dordrecht-Boston-London.

Davies, F.T. and H.T. Hartmann. 1988. The physiological basis of adventitious root formation. Acta Hort. 227:113-120.

Davis, T.D., B.E. Haissig, and N. Sankhla. 1988. Adventitious root formation in cuttings, $\mathrm{p}$. 315. Advances in plant sciences series. vol. 2. Dioscorides press, Portland, Ore.

Epstein, E., and J. Ludwig-Müller. 1993. Indole3-butyric acid in plants: occurrence, synthesis, metabolism and transport. Physiol. Plant. 88:382-389.

Gulen, H., Y. Erbil, and A. Eris. 2004. Improved rooting of Gisela-5 softwood cuttings follow- ing banding and IBA application. HortScience 39:1403-1405.

Hartmann, H.T., D.E. Kester, F.T. Davies, Jr., and R.L. Geneve. 1997. Plant propagation: Principles and practice. 6th ed. p. 770. Prentice hall, Upper Saddle River, N.J.

De Klerk, G.-J., W. Van der Krieken, and J.C. De Jong. 1999. The formation of adventitious roots: new concepts, new possibilities. In Vitro Cell. Dev. Biol.-Plant. 35:189-199.

Kovač, M., D. Piskernik, and M. Ravnikar. 2003. Jasmonic acid-induced morphological changes are reflected in auxin metabolism of beans grown in vitro. Biol. Plant. 47:273-275.

Loach, K. 1988. Hormone applications and adventitious root formation in cuttings-A critical review. Acta Hort. 227:126-133.

Ludwig-Müller, J. 2000. Indole-3-butyric acid in plant growth and development. Plant Growth Regulat. 32:219-230.

Nordström, A.-C., F.A. Jacobs, and L. Eliasson. 1991. Effect of exogenous indole-3-acetic acid and indole-3-butyric acid on internal levels of the respective auxins and their conjugation with aspartic acid during adventitious root formation in pea cuttings. Plant Physiol. 96:856-861.

Osterc, G. and W. Spethmann. 1998. Kirschen- und Apfelunterlagen durch Stecklinge vermehren? Deutsche Baumschule 10:18-21.

Osterc, G. and W. Spethmann. 2001. Studies on auxin uptake in Prunus and Malus green cuttings. Prop. Ornamental Plants 1:3-9.

Riov, J. 1993. Endogenous and exogenous auxin conjugates in rooting of cuttings. Acta Hort. 329:284-288

Spethmann, W. 2000. Autovegetative Gehölzvermehrung, p. 58-125. In: D. Mac Carthaigh, and W. Spethmann (eds.). Krüssmanns Gehölzvermehrung. Blackwell Wissenschafts-Verlag, Berlin, Wien.

Spethmann, W., and A. Hamzah. 1988. Growth hormone induced root system types in cuttings of some broad leaved tree species. Acta Hort. 226:601-605.

Trobec, M., F. Štampar, R. Veberič, and G. Osterc. 2005. Fluctuations of different endogenous phenolic compounds and cinnamic acid in the first days of the rooting process of cherry rootstock 'GiSelA 5' leafy cuttings. J. Plant Physiol. 162:589-597.

Wiesman, Z., J. Riov, and E. Epstein. 1988. Comparison of movement and metabolism of indole3-acetic acid and indole-3-butyric acid in mung bean cuttings. Physiol. Plant. 74:556-560.

Wiesman, Z., J. Riov, and E. Epstein. 1989. Characterization and rooting ability of indole-3-butyric acid conjugates formed during rooting of mung bean cuttings. Plant Physiol. 91:1080-1084.

Wiesman, Z., and S. Lavee. 1995. Enhancement of IBAstimulatory effect on rooting of olive cultivar stem cuttings. Sci. Hort. 62:189-198.

Yang, T., and P.J. Davies. 1999. Promotion of stem elongation by indole-3-butyric acid in intact plants of Pisum sativum L. Plant Growth Regulat. 27:157-160. 